\title{
Sordaria macrospora: 25 years as a model organism for studying the molecular mechanisms of fruiting body development
}

\author{
Ines Teichert ${ }^{1} \cdot$ Stefanie Pöggeler ${ }^{2} \cdot$ Minou Nowrousian ${ }^{3}$
}

Received: 24 January 2020 / Revised: 19 February 2020 / Accepted: 26 February 2020 / Published online: 11 March 2020

(C) The Author(s) 2020

\begin{abstract}
Fruiting bodies are among the most complex multicellular structures formed by fungi, and the molecular mechanisms that regulate their development are far from understood. However, studies with a number of fungal model organisms have started to shed light on this developmental process. One of these model organisms is Sordaria macrospora, a filamentous ascomycete from the order Sordariales. This fungus has been a genetic model organism since the 1950s, but its career as a model organism for molecular genetics really took off in the 1990s, when the establishment of a transformation protocol, a mutant collection, and an indexed cosmid library provided the methods and resources to start revealing the molecular mechanisms of fruiting body development. In the 2000s, "omics" methods were added to the S. macrospora tool box, and by 2020, 58 developmental genes have been identified in this fungus. This review gives a brief overview of major method developments for $S$. macrospora, and then focuses on recent results characterizing different processes involved in regulating development including several regulatory protein complexes, autophagy, transcriptional and chromatin regulation, and RNA editing.
\end{abstract}

\section{Key points}

-Sordaria macrospora is a model system for analyzing fungal fruiting body development.

- More than 100 developmental mutants are available for S. macrospora.

-More than 50 developmental genes have been characterized in $S$. macrospora.

Keywords Sordaria macrospora - Multicellular development · Fruiting body · Sexual development · Analysis of mutants . Genomics $\cdot$ Transcriptomics $\cdot$ Autophagy $\cdot$ RNA editing

\section{Introduction}

Sordaria macrospora is a filamentous ascomycete with a decades-long history as a model organism to study fruiting

This article is dedicated to Prof. Dr. Ulrich Kück (Bochum) on the occasion of his 70th birthday.

Minou Nowrousian

minou.nowrousian@rub.de

1 General and Molecular Botany, Ruhr-University Bochum, 44780 Bochum, Germany

2 Institute of Microbiology and Genetics, Department of Genetics of Eukaryotic Microorganisms, Georg-August University,

Göttingen, Germany

3 Department of Molecular and Cellular Botany, Ruhr-University Bochum, ND 7/176 Universitätsstr. 150, 44780 Bochum, Germany body development, one of the most complex forms of multicellular development in fungi (Kück et al. 2009; Engh et al. 2010; Teichert et al. 2014a; Nagy et al. 2018). One reason for its success as a model organism is its short life cycle, which takes only 7 days to be completed under laboratory conditions. Furthermore, S. macrospora is homothallic, i.e., self-fertile, which means that a single strain can complete the life cycle without the need of a mating partner. Thus, after inoculation on a Petri dish, no further steps (e.g., fertilization) are required to complete the sexual cycle, which leads to the production of meiotic spores (ascospores) within fruiting bodies (Fig. 1, Fig. 2). Ascospores are the only spores produced by S. macrospora, since this fungus lacks any vegetative sporulation. This lack of vegetative spores facilitates handling in the laboratory, because there is less danger of contamination. In recent years, the lack of vegetative spores turned out to have other benefits, namely in transcriptomics studies, because gene expression changes during the sexual cycle are not 

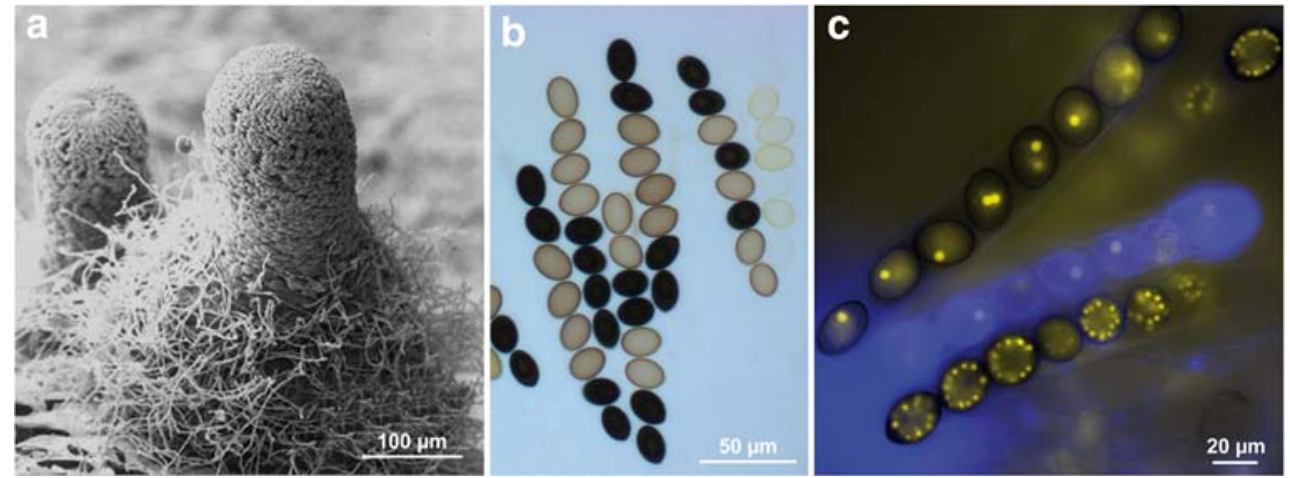

Fig. 1 Fruiting bodies and asci of S. macrospora. a Scanning electron micrograph of a fruiting body (perithecium). b Light microscopy of asci from a cross between the wild type (black spores) and a spore color mutant with yellow spores. c Fluorescence microscopy of asci and ascopores. Nuclei are labeled with YFP-tagged histones. In the upper ascus, each ascospore contains one to two nuclei. In the lower ascus, each ascospore contains several nuclei after several mitotic divisions. Pictures from Pöggeler et al. (2018) with permission by Springer Nature confounded by other developmental processes running in parallel (Teichert et al. 2014a).

Despite being homothallic, $S$. macrospora is also able to outcross; therefore different strains, e.g., developmental mutants, can be crossed in the laboratory (Esser and Straub 1956). For such classical genetic analyses, another advantage of $S$. macrospora is the production of its ascospores as ordered tetrads, which means that each ascus (meiosporangium) contains the four meiotic products of a single meiosis, and that the order of spores in the ascus allows distinguishing between alleles that segregated in the first versus the second meiotic division (Kück et al. 2009). Especially, the ordered tetrads make $S$. macrospora also a model organism for studying the molecular mechanisms of meiosis. This was reviewed recently by Zickler and Espagne (2016), whereas the focus of this review will be on the use of $S$. macrospora as a model organism for fruiting body development.

The first studies of fruiting body development in $S$. macrospora were conducted in the 1950 s using X-ray mutagenesis and genetic crosses (Esser and Straub 1958). However, $S$. macrospora truly began its career as a model organism for fruiting body development with its entry into the world of molecular techniques 25 years ago, starting with the establishment of a transformation system by Walz and Kück (1995). Shortly afterwards, two important resources were developed for $S$. macrospora, namely a mutant collection of more than 100 developmental mutants generated by chemical or UV mutagenesis, and an indexed cosmid library that could be used to transform mutants to fertility, thereby identifying the defective genes in the mutant strains (Pöggeler et al. 1997; Masloff et al. 1999; Kück et al. 2009). In the following years, the developmental genes acl1, pro1, pro11, pro22, pro40, and pro41 were identified by complementing sterile mutant strains with an indexed cosmid library (Masloff et al. 1999; Nowrousian et al. 1999; Pöggeler and Kück 2004; Engh et al. 2007b; Nowrousian et al. 2007; Bloemendal et al.
2010). Subsequent analyses of the functions of the corresponding proteins revealed that most of these genes encode members of conserved protein complexes involved in developmental signal transduction, thereby showing the value of a mutant collection with distinct developmental phenotypes (Table 1, Fig. 2).

About 15 years ago, S. macrospora entered the "omics" age, first in the form of transcriptomics by cross-species microarray hybridization. This technique made use of the close phylogenetic relationship between $S$. macrospora and Neurospora crassa (Nowrousian et al. 2004), which meant that available microarrays with $N$. crassa probes (Lewis et al. 2002; Nowrousian et al. 2003) could be hybridized with targets derived from $S$. macrospora (Nowrousian et al. 2005). Cross-species hybridization was used to characterize expression profiles of the wild type and several developmental mutants (Nowrousian et al. 2005; Pöggeler et al. 2006; Nowrousian et al. 2007; Klix et al. 2010).

Ten years ago, $S$. macrospora was the second eukaryote (the first was the giant panda ( $\mathrm{Li}$ et al. 2010)), and the first fungus, to have its genome sequenced solely by nextgeneration sequencing techniques (Nowrousian et al. 2010). By now, two updated versions of the genome sequence have been published with improved annotation, the first based on RNA-seq, and the second based on proteogenomics (Teichert et al. 2012; Blank-Landeshammer et al. 2019). The availability of a genome sequence enabled the use of many other sequencing-based techniques for $S$. macrospora. One was the identification of defective genes in mutant strains by genome sequencing instead of the more laborious complementation by transformation. Mutant sequencing was done as bulk segregant analysis, a powerful approach that is possible only in model organisms where classical genetics can be combined with molecular and bioinformatics methods. Bulk segregant analysis was used to identify the developmental genes mikl, nox 1, pro44, spd4, and tih (Nowrousian et al. 2012; 


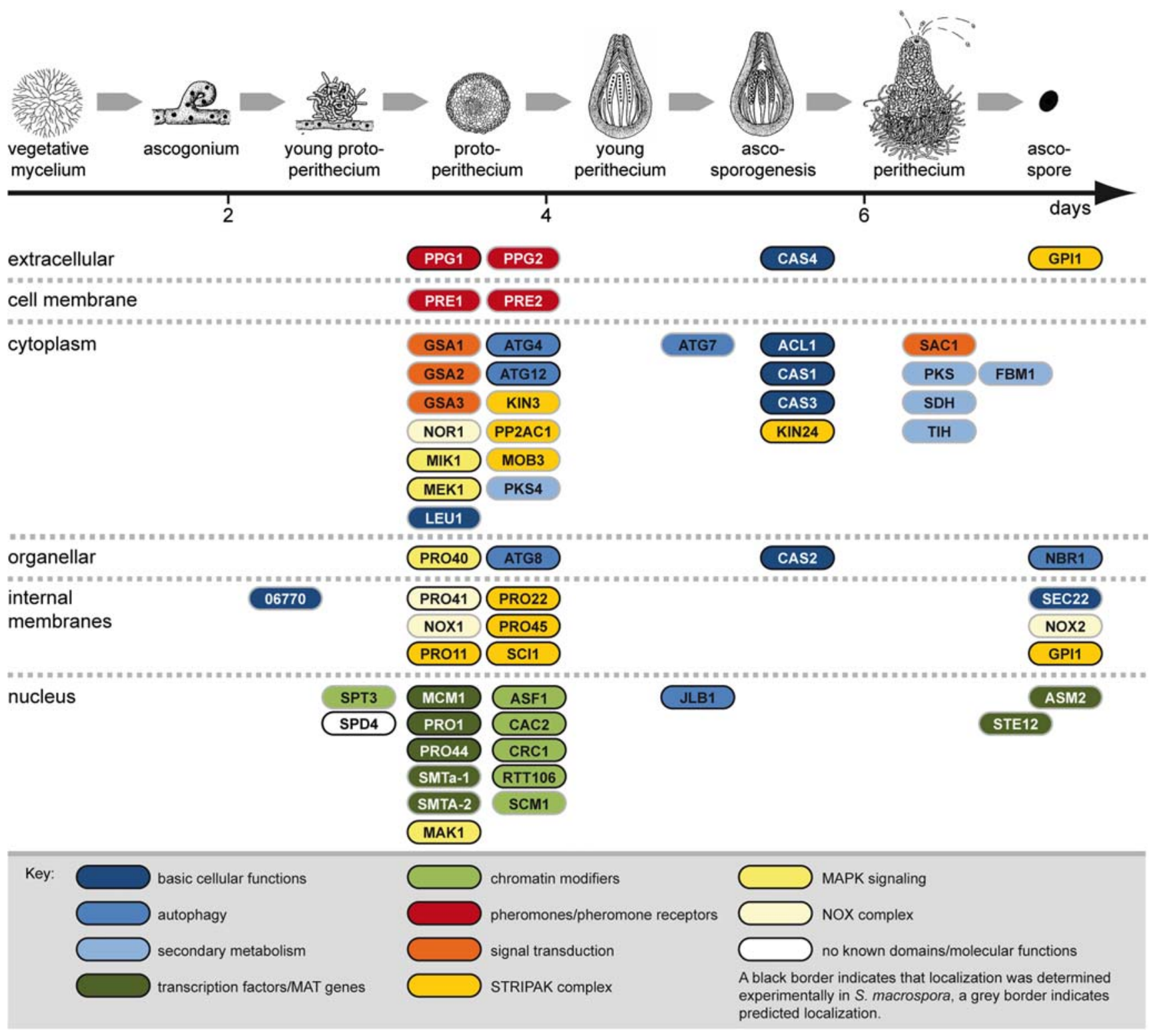

Fig. 2 Overview of developmental proteins from S. macrospora. Proteins are sorted vertically according to their subcellular localization (indicated on the left), and horizontally according to the developmental stage during which they are required (indicated on top) based on the phenotypes of the corresponding mutants. Pictures of life cycle stages from Kück et al. (2009) with permission by Springer Nature
Dirschnabel et al. 2014; Teichert et al. 2014b; Teichert et al. 2017b). The availability of a genome sequence also facilitated the use of RNA-seq for transcriptomics studies. Laser microdissection in combination with RNA-seq was used to analyze gene expression patterns in developing fruiting bodies in S. macrospora alone or in comparative transcriptomics studies where gene expression during development was compared between $S$. macrospora and other fungal species to identify evolutionary conserved expression patterns (Teichert et al. 2012; Traeger et al. 2013; Dirschnabel et al. 2014; Schumacher et al. 2018; Lütkenhaus et al. 2019).

Differentially expressed genes identified through transcriptomics of mutants or comparative transcriptomics of different species turned out to be good candidates for further functional analyses to identify novel developmental genes by reverse genetics. The generation of deletion mutants by homologous recombination for such candidate genes was facilitated by the availability of a $\Delta \mathrm{ku} 70$ strain, which has a lower frequency of ectopic integration, leading to a higher proportion of targeted deletions in the resulting transformants (Pöggeler and Kück 2006). Deletion of differentially expressed candidate genes led to the identification of developmental genes asf1, asm 2, crcl, scm 1, sec22, SMAC 06770, SmJLB1, and spt3 (Gesing et al. 2012; Voigt et al. 2013; Traeger and Nowrousian 2015; Schumacher et al. 2018; Lütkenhaus et al. 2019). 
Table 1 Developmental genes from $S$. macrospora. References: [1] (Masloff et al. 1999), [2] (Nowrousian et al. 1999), [3] (Pöggeler and Kück 2004), [4] (Kück 2005), [5] (Mayrhofer and Pöggeler 2005), [6] (Mayrhofer et al. 2006), [7] (Nolting and Pöggeler 2006a), [8] (Nolting and Pöggeler 2006b), [9] (Pöggeler et al. 2006), [10] (Engh et al. 2007a), [11] (Engh et al. 2007b), [12] (Nowrousian et al. 2007), [13] (Kamerewerd et al. 2008), [14] (Elleuche and Pöggeler 2009), [15] (Nolting et al. 2009), [16] (Nowrousian 2009), [17] (Bloemendal et al. 2010), [18] (Klix et al. 2010), [19] (Bernhards and Pöggeler 2011), [20]
(Bloemendal et al. 2012), [21] (Gesing et al. 2012), [22] (Nowrousian et al. 2012), [23] (Voigt and Pöggeler 2013a), [24] (Voigt et al. 2013), [25] (Dirschnabel et al. 2014), [26] (Lehneck et al. 2014), [27] (Schindler and Nowrousian 2014), [28] (Teichert et al. 2014b), [29] (Frey et al. 2015a), [30] (Frey et al. 2015b), [31] (Nordzieke et al. 2015), [32] (Traeger and Nowrousian 2015), [33] (Beier et al. 2016), [34] (Werner et al. 2016), [35] (Teichert et al. 2017b), [36] (Radchenko et al. 2018), [37] (Reschka et al. 2018), [38] (Schumacher et al. 2018), [39] (Lütkenhaus et al. 2019), [40] (Werner et al. 2019)

\begin{tabular}{|c|c|c|c|}
\hline Gene & Locus tag number & Gene product/conserved domains & Ref. \\
\hline \multicolumn{4}{|c|}{ Primary metabolism and basic cellular functions } \\
\hline acll & SMAC_06775 & Subunit of the ATP citrate lyase & {$[2]$} \\
\hline cas 1 & SMAC_03420 & $\beta$-class carbonic anhydrase & {$[14,26]$} \\
\hline $\operatorname{cas} 2$ & SMAC_03614 & $\beta$-class carbonic anhydrase & {$[14,26]$} \\
\hline cas 3 & SMAC_03179 & $\beta$-class carbonic anhydrase & {$[14,26]$} \\
\hline cas 4 & SMAC_03821 & $\alpha$-class carbonic anhydrase & {$[26]$} \\
\hline leul & SMAC_07802 & $\beta$-isopropylmalate dehydrogenase & {$[4]$} \\
\hline $\sec 22$ & SMAC_06625 & SNARE protein & {$[32]$} \\
\hline-- & SMAC_06770 & Putative glycolipid 2-alpha-mannosyltransferase & {$[39]$} \\
\hline \multicolumn{4}{|c|}{ Autophagy genes } \\
\hline Smatg4 & SMAC_08321 & Cysteine protease & {$[23]$} \\
\hline Smatg7 & SMAC_06539 & E1-like enzyme & {$[15]$} \\
\hline Smatg8 & SMAC_02305 & Ubiquitin-like protein & {$[23]$} \\
\hline Smatg12 & SMAC_06998 & Ubiquitin-like protein & {$[34]$} \\
\hline Smjlb1 & SMAC_08510 & bZIP transcription factor & {$[24]$} \\
\hline Smnbrl & SMAC_07844 & Autophagy cargo receptor & {$[40]$} \\
\hline \multicolumn{4}{|c|}{ Secondary metabolism } \\
\hline$f b m 1$ & SMAC_00522 & Monooxygenase & {$[16]$} \\
\hline pks4 & SMAC_05695 & Reducing polyketide synthase & {$[27]$} \\
\hline pks & SMAC_03130 & Polyketide synthase (melanin biosynthesis) & {$[10]$} \\
\hline$s d h$ & SMAC_02101 & Scytalone dehydratase (melanin biosynthesis) & {$[10]$} \\
\hline tih & SMAC_05650 & Trihydroxynaphtalene reductase (melanin biosynthesis) & {$[10,22]$} \\
\hline \multicolumn{4}{|c|}{ Transcription factors and mating-type genes } \\
\hline asm2 & SMAC_09436 & GAL4-like zinc cluster transcription factor & {$[38]$} \\
\hline mcml & SMAC_05219 & MADS-box transcription factor & {$[8]$} \\
\hline prol & SMAC_00338 & $\mathrm{C}_{6}$ zinc finger transcription factor & {$[1]$} \\
\hline pro44 & SMAC_03223 & GATA-type transcription factor & {$[22,38]$} \\
\hline Smta-1 & SMAC_05404 & MAT1-2-1, HMG domain transcription factor & {$[9]$} \\
\hline SmtA-2 & SMAC_05402 & MAT1-1-2, PPF domain protein & {$[18]$} \\
\hline ste12 & SMAC_06479 & Homeodomain/zinc finger transcription factor & [7] \\
\hline \multicolumn{4}{|c|}{ Chromatin modifiers } \\
\hline asfl & SMAC_08608 & $\mathrm{H} 3 / \mathrm{H} 4$ histone chaperone & {$[21,38]$} \\
\hline$c a c 2$ & SMAC_01629 & Putative subunit of CAF-1 (chromatin assembly factor 1) & {$[21,38,39]$} \\
\hline crcl & SMAC_02795 & CRC domain protein & {$[38,39]$} \\
\hline$r t t 106$ & SMAC_03589 & Putative $\mathrm{H} 3 / \mathrm{H} 4$ histone chaperone & {$[21,38,39]$} \\
\hline scml & SMAC_04946 & SAS4 domain protein & {$[39]$} \\
\hline spt3 & SMAC_01829 & Putative subunit of the SAGA complex & {$[39]$} \\
\hline \multicolumn{4}{|c|}{ Pheromones and pheromone receptors } \\
\hline ppg1 & SMAC_05970 & Peptide pheromone & {$[5]$} \\
\hline ppg2 & SMAC_12967 & Lipopeptide pheromone & {$[6]$} \\
\hline prel & SMAC_02283 & Pheromone receptor & {$[6]$} \\
\hline pre2 & SMAC_08994 & Pheromone receptor & {$[6]$} \\
\hline
\end{tabular}


Table 1 (continued)

\begin{tabular}{|c|c|c|c|}
\hline Gene & Locus tag number & Gene product/conserved domains & Ref. \\
\hline \multicolumn{4}{|c|}{ Signal transduction } \\
\hline gsal & SMAC_05328 & G protein $\alpha$-subunit & {$[13]$} \\
\hline gsa2 & SMAC_06605 & G protein $\alpha$-subunit & {$[13]$} \\
\hline gsa3 & SMAC_07195 & G protein $\alpha$-subunit & {$[13]$} \\
\hline sacl & SMAC_01638 & Adenylate cyclase & {$[13]$} \\
\hline \multicolumn{4}{|c|}{ Subunits of the STRIPAK complex } \\
\hline pp2Acl & $S M A C \_04678$ & Catalytic subunit of protein phosphatase $2 \mathrm{~A}$ & {$[33]$} \\
\hline proll & SMAC_08794 & Striatin & {$[3]$} \\
\hline pro22 & SMAC_02580 & STRIP & {$[17,20]$} \\
\hline pro45 & SMAC_01224 & SLMAP & {$[31]$} \\
\hline SCI1 & SMAC_05559 & STRIPAK complex interactor 1 & {$[37]$} \\
\hline Smgpil & SMAC_12074 & GPI-anchored protein & {$[29]$} \\
\hline Smkin3 & SMAC_04490 & Germinal center kinase & {$[30,36]$} \\
\hline Smkin24 & SMAC_01456 & Germinal center kinase & {$[30]$} \\
\hline Smmob3 & SMAC_00877 & Phocein & {$[19]$} \\
\hline \multicolumn{4}{|c|}{ MAPK signaling } \\
\hline makl & SMAC_05504 & MAPK of CWI pathway & {$[28]$} \\
\hline mek1 & SMAC_02183 & MAPK kinase (MAPKK) of CWI pathway & {$[28]$} \\
\hline mikl & SMAC_03673 & MAPK kinase kinase (MAPKKK) of CWI pathway & {$[28]$} \\
\hline pro40 & SMAC_04815 & Scaffold protein for CWI pathway & {$[11,28]$} \\
\hline \multicolumn{4}{|c|}{ NOX complex } \\
\hline norl & SMAC_02124 & NOX regulator & {$[25]$} \\
\hline noxl & SMAC_05007 & NADPH oxidase & {$[25]$} \\
\hline nox 2 & SMAC_08741 & NADPH oxidase & {$[25]$} \\
\hline pro41 & $S M A C \_04848$ & ER membrane protein, NoxD homolog & {$[12]$} \\
\hline \multicolumn{4}{|c|}{ Genes without known domains or known molecular functions } \\
\hline $\operatorname{spd4}$ & SMAC_01964 & - & {$[35]$} \\
\hline
\end{tabular}

$C W I$, cell wall integrity pathway; $E R$, endoplasmic reticulum; $G P I$, glycosylphosphatidylinositol; $M A P K$, mitogen-activated protein kinase; NOX, NADPH oxidase; SAGA, Spt-Ada-Gen5 histone acetyltransferase; SLMAP, sarcolemmal membrane-associated protein; SNARE, soluble Nethylmaleimide-sensitive-factor attachment protein receptor; STRIPAK, striatin-interacting phosphatase and kinase; STRIP, striatin-interacting protein

In addition to "omics"-based methods, fluorescence microscopy was used extensively to study fruiting body development in S. macrospora. For this purpose, the use of the green fluorescent protein (GFP) and fluorescent proteins for other wavelengths was established in this fungus, and also the use of superresolution structured illumination microscopy (SIM) to identify the subcellular localization of developmental proteins (Pöggeler et al. 2003; Rech et al. 2007; Nordzieke et al. 2015).

By 2020, 58 developmental genes have been identified and characterized in $S$. macrospora, and a better picture of the molecular processes involved in fruiting body formation is starting to emerge (Table 1, Fig. 2). Several previous reviews describe earlier studies using $S$. macrospora as a model organism (Kück et al. 2009; Engh et al. 2010; Teichert et al. 2014a), and therefore, the next sections of this review will focus on more recent results.

\section{Analysis of developmental mutants reveals the role of multi-protein complexes in fruiting body development}

One of the major advantages when working with $S$. macrospora is the availability of two large mutant libraries containing developmental mutants blocked at different stages of fruiting body formation. These mutants were generated by classical mutagenesis, using X-ray, UV light, and ethyl methanesulfonate (EMS) (Esser and Straub 1958; Kück et al. 2009). By characterizing these mutants, we found base substitutions or deletions in protein-coding genes that are essential for fruiting body formation. Research with $S$. macrospora has mostly focused on "pro" mutants that are blocked after the formation of protoperithecia (Fig. 2). Starting from single PRO proteins, further research revealed links between different PRO proteins and their interaction partners, leading to the 
Fig. 3 Components of the striatin-interacting phosphatase and kinase (STRIPAK) complex, the cell wall integrity (CWI) mitogen-activated kinase (MAPK) cascade, and two NADPH oxidase (NOX) complexes in S. macrospora. For coloring of proteins see key to Fig. 2

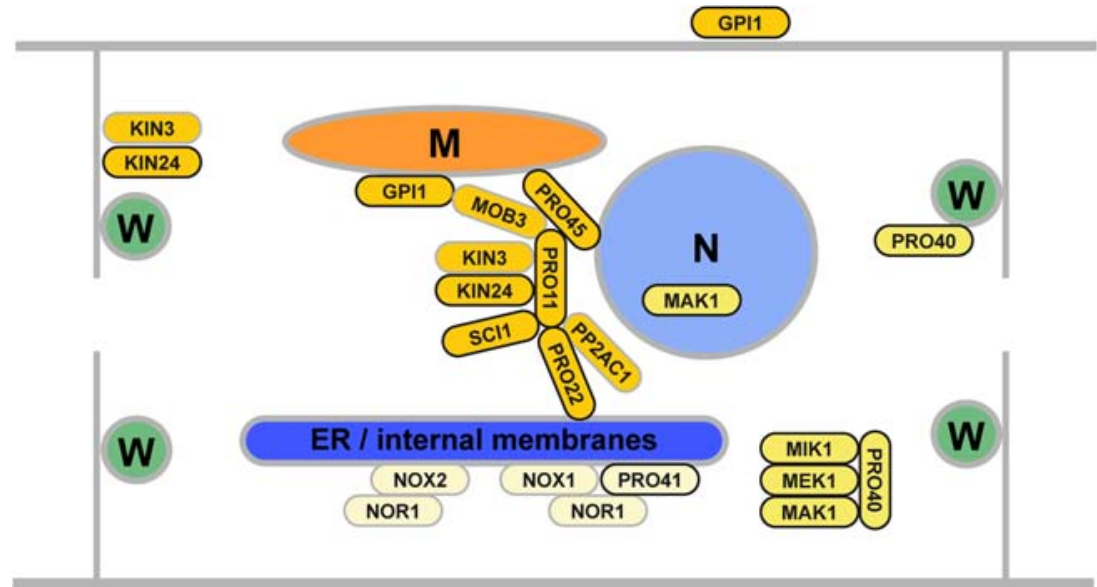

ER: endoplasmic reticulum, M: mitochondrion, N: nucleus, W: Woronin body identification of several multi-protein complexes regulating sexual development. This section will focus on the striatininteracting phosphatase and kinase (STRIPAK) complex, the cell wall integrity (CWI) mitogen-activated kinase (MAPK) cascade, and two NADPH oxidase (NOX) complexes and their role in sexual development of S. macrospora (Fig. 3).

The STRIPAK complex is a highly conserved eukaryotic protein complex assembled around the trimeric protein phosphatase 2A (PP2A) (Goudreault et al. 2009). This phosphatase consists of three subunits, the scaffolding subunit PP2AA, a catalytic subunit, and a regulatory subunit. Different regulatory subunits target the phosphatase to specific proteins. The first STRIPAK subunit characterized in fungi was PRO11, homologous to human striatins that serve as regulatory PP2A subunits within STRIPAK (Pöggeler and Kück 2004; Bloemendal et al. 2012). Complementation of the pro11 mutant with cosmids from an indexed library (Pöggeler et al. 1997) led to the identification of a premature stop codon in the mutant pro11 ORF (Pöggeler and Kück 2004). Similarly, a premature stop codon in mutant pro22 was detected, and later studies identified an interaction between PRO11 and PRO22 (Bloemendal et al. 2010; Bloemendal et al. 2012). PRO22 is homologous to striatin-interacting proteins and also belongs to the STRIPAK core, similar to one of two PP2A catalytic subunits, PP2Ac1 (Beier et al. 2016). Additional associated subunits include the SLMAP homolog PRO45, the phocein homolog MOB3, germinal center kinases Smkin3 and Smkin24, the small coiled-coil protein SCI1, and the GPI-anchored protein Smgpil (Bernhards and Pöggeler 2011; Frey et al. 2015a; Frey et al. 2015b; Nordzieke et al. 2015; Radchenko et al. 2018; Reschka et al. 2018) (see Table 1). A common phenotype of core STRIPAK mutants in S. macrospora is their lack of fruiting bodies, development arrests after the formation of protoperithecia (Kück et al. 2016). This phenotype is shared with $\Delta$ mob3, $\Delta$ pro45, and $\Delta$ scil (Bernhards and Pöggeler 2011; Nordzieke et al. 2015; Reschka et al. 2018). Besides a general role in fruiting body formation, distinct STRIPAK subunits have additional functions, e.g., PRO22, PP2Ac1, and SmKIN3 in ascogonial septum formation (Bloemendal et al. 2010; Beier et al. 2016; Radchenko et al. 2018).

The cell wall integrity pathway was characterized when genome sequencing of mutant pro30 revealed that a defect in the MAPK kinase (MAPKK) gene mek1 caused the sterile phenotype (Teichert et al. 2014b). Protein-protein interaction studies showed that the pathway consists of MAPK kinase kinase (MAPKKK) MIK1, MAPKK MEK1, and MAPK MAK1 (see Table 1). Further upstream components include protein kinase $\mathrm{C}$ (PKC1) and the small $\mathrm{G}$ protein $\mathrm{RHO} 1$ (Teichert et al. 2014b). Furthermore, it was shown that MAPKK MEK1 interacts with PRO40, a protein that had previously been described as being essential for fruiting body formation and hyphal fusion (Engh et al. 2007b, Rech et al. 2007). PRO40 interacts with MEK1, MIK1, and PKC1. MIK1 and PKC1 do not interact in a yeast two-hybrid assay; thus, PRO40 mediates the interaction of the MAPK module with the upstream kinase (Teichert et al. 2014b). In vivo phosphorylation assays showed that phosphorylation of the MAPK MAK1 is strongly reduced in $\Delta$ pro40 during development and stress response. Therefore, PRO40 acts as a scaffold protein for the CWI MAPK pathway during these processes. However, yet unknown scaffold proteins are required for CWI pathway functions in cell wall integrity.

Studies of the $S$. macrospora NOX complexes include the analysis of the two mutants pro32, showing a defect in the nox 1 gene, and pro41, having a defect in the pro41 gene that is homologous to noxD from Botrytis cinerea and Podospora anserina (Nowrousian et al. 2007; Dirschnabel et al. 2014). NOXD is a membrane protein interacting with NOX1 homologs in fungi and in higher eukaryotes (Lacaze et al. 2015; Siegmund et al. 2015). NOXs are important for the generation of reactive oxygen species (ROS) by oxidation of NADPH (Lambeth 2004). Importantly, it has been hypothesized that ROS do not only act in a damaging way, but that they also act as signaling molecules that drive developmental processes 
(Scott and Eaton 2008; Aguirre and Lambeth 2010; Heller and Tudzynski 2011). Two NOX complexes exist in $S$. macrospora, the NOX1 complex containing NOX1 and most probably PRO41 as well as the NOX2 complex containing NOX2. Both complexes further contain the NOX regulator NOR1 (Dirschnabel et al. 2014). The NOX1 complex controls the maturation of protoperithecia to perithecia, vegetative hyphal fusion, and vegetative growth as well as oxidative stress response. The NOX2 complex regulates the germination of ascospores. Interestingly, nox 2 and nor 1 deletion mutants germinate only in a melanin-deficient background. This phenomenon may be caused by quenching of residual reactive oxygen species by melanin in the ascospore cell wall. In a brown-spored fus mutant defective of melanin production, the residual ROS may be sufficient to trigger germination (Dirschnabel et al. 2014).

Taken together, several developmental mutants have aided in the identification of multi-protein complexes that control fruiting body formation. These results highlight the advantages of forward genetic screens for the characterization of distinct developmental processes.

\section{Autophagy: the role of cellular recycling in fruiting body development}

All eukaryotes, including fungi, have conserved mechanisms for recycling cytosolic material in times of stress or during cellular differentiation processes. Recent findings have revealed that autophagy (literally, self-eating) plays a key role in fungal development and pathogenicity (Bartoszewska and Kiel 2011; Voigt and Pöggeler 2013b; Pöggeler et al. 2018; Zhu et al. 2019). During autophagy, a double lipid bilayer surrounds parts of the cytoplasm including organelles, expands, closes, and forms a double-membraned vesicle, called the autophagosome (Fig. 4). These autophagosomes are delivered to the vacuole for degradation. The outer membrane of the autophagosome fuses with the vacuolar membrane and releases the single-membraned autophagic body into the lumen of the vacuole. In the vacuole, the autophagic body and its content are hydrolyzed by vacuolar enzymes, and metabolites are transported back into the cytoplasm via vacuolar permeases for reuse (Wen and Klionsky 2016).

Autophagy relies on autophagy-related genes (atg) genes. The process requires in yeast 19 core ATG proteins that regulate initiation, nucleation and expansion of the phagophore membrane, completion of the autophagosome, docking and fusion with the vacuolar membrane, degradation, and recycling (Fig. 4) (Ohsumi 2014). Most of these core atg genes are conserved among eukaryotes including filamentous fungi (Bartoszewska and Kiel 2011; Voigt and Pöggeler 2013b). The random engulfment of cytoplasm by autophagosomes is called non-selective autophagy. In addition, selective autophagy leads to the specific, vacuolar degradation of superfluous or damaged organelles like ribosomes, peroxisomes, mitochondria, nuclei, and the ER, by ribophagy, pexophagy, mitophagy, nucleophagy, and ERphagy, respectively (Farré and Subramani 2016).

Mining of the published S. macrospora genome sequence (Nowrousian et al. 2010) revealed the coding capacity for 17 core atg genes. However, the S. macrospora genome does not encode clear orthologs of Saccharomyces cerevisiae ATG proteins required for selective autophagy (Voigt and Pöggeler 2013b; Teichert et al. 2014a).

To determine whether non-selective autophagy is necessary for vegetative growth and fruiting body development in S. macrospora, we characterized the function of core autophagic proteins of the Ubl conjugation systems. Budding yeast has two ubiquitin-like-conjugation systems, which are involved in autophagosome formation and expansion. The ubiquitin-like protein ATG12 is covalently attached to ATG5 by the action of the E1-like enzyme ATG7 and the E2-like enzyme ATG10. In the second conjugation system, the ubiquitin-like protein ATG8 is C-terminally processed by the cysteine protease ATG4 and then activated by ATG7 and transferred to the E2like enzyme ATG3. Finally, a conjugate of ATG8 and phosphatidylethanolamine (PE) is formed by the E3-like complex ATG12/ATG5/ATG16. The ATG8-PE conjugate is a structural component of the outer and inner autophagosomal membrane (Fig. 4) (Ohsumi 2001). In addition to processing the ATG8 precursor, the ATG4 protease acts as a deconjugating enzyme and facilitates the recycling of ATG8 from the outer membrane of the autophagosome (Kirisako et al. 2000).

In $S$. macrospora, we were not able to generate a homokaryotic $\Delta$ Smatg7 mutant, suggesting that E1-like enzyme SmATG7 is required for viability (Nolting et al. 2009). However, we succeeded to delete Smatg4, Smatg8, and Smatg12. All three homokaryotic deletion mutants are impaired in vegetative growth and stop fruiting body development at the stage of protoperithecia formation. In this regard, core autophagy mutants resemble pro mutants of S. macrospora; though in contrast to many pro mutants, they are not impaired in hyphal fusion (Voigt and Pöggeler 2013a; Werner et al. 2016). For SmATG4, we demonstrated that the protease is capable of processing SmATG8. Localization studies revealed that SmATG8 localizes to autophagosomes, SmATG12 to phagophores, and SmATG4 is distributed throughout the cytoplasm. We could also show that Smatg8 and Smatg4 are required not only for nonselective macroautophagy, but for selective pexophagy as well (Voigt and Pöggeler 2013a). Smatg4 and Smatg8 genes are transcriptionally repressed by the bZIP transcription factor SmJLB1 (Voigt et al. 2013). Moreover, we showed that vps34 and vps 15 , encoding components of the PI3K complex and the vacuolar protein sorting complex, are required for viability of $S$. macrospora (Voigt et al. 2014). These 


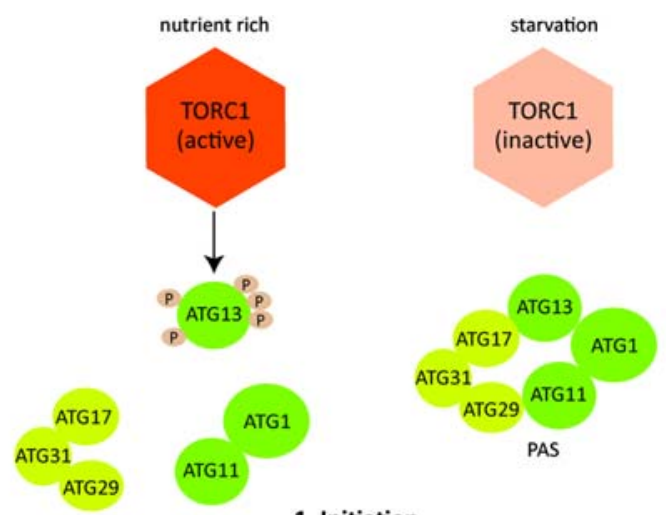

1. Initiation

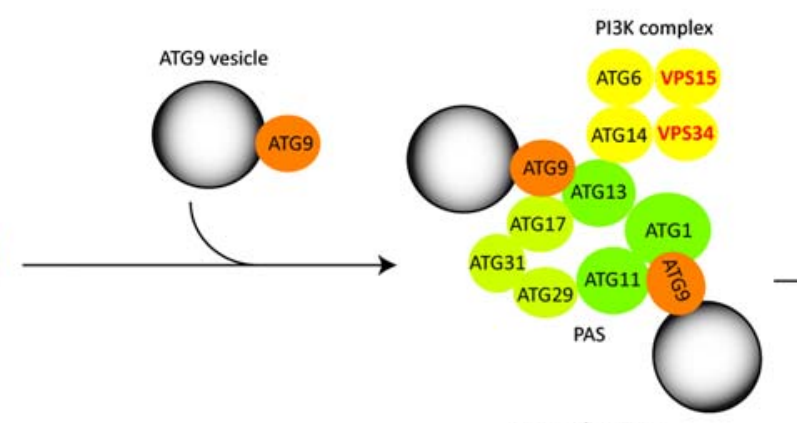

2. Nucleation

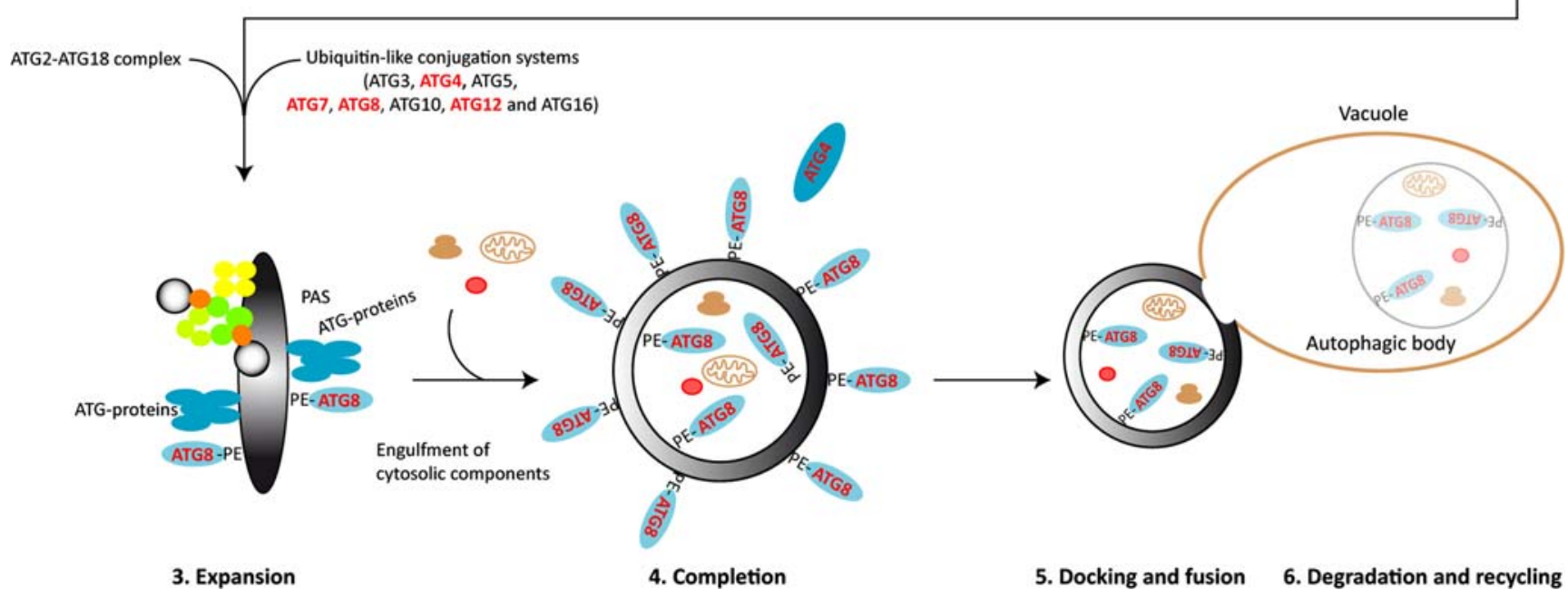

Fig. 4 Major stages in non-selective autophagy in $S$. cerevisiae. The process of autophagy can be divided into six steps: (1) Under nutrientrich conditions, the active TOR kinase phosphorylates ATG13. Hyperphosphorylation of ATG13 prevents an interaction with the kinase ATG1 and the scaffold protein ATG17. After inactivation of TOR during starvation or rapamycin treatment, the hypophosphorylated ATG13 forms a complex with the ATG1 kinase and the tripartite ATG17-ATG31ATG29 complex as well as the adaptor protein ATG11 at the phagophore assembly site (PAS). (2) Nucleation involves recruitment of ATG9 vesicles and the phosphoinositide-3-kinase (PI3K) complex composed of ATG6, ATG14, and the vacuolar sorting proteins VPS34 and VPS15. (3) Expansion of the PAS to a phagophore requires the recruitment of the ATG2-ATG18 complex and the ubiquitin-like (Ubl) conjugation

results suggest that in $S$. macrospora, autophagy is an essential and constitutively active process required to maintain high energy levels for filamentous growth and multicellular development.

To examine to which extent selective autophagy contributes to fungal fruiting body development, we applied a GFPTrap analysis with EGFP-SmATG8 to identify SmATG8interacting proteins. Among proteins expected to interact with ATG8, such as ATG3 and ATG7, the mammalian homolog of the mammalian cargo receptor NBR1, SmNBR1, was identified as an interaction partner of SmATG8 (Werner et al. 2019). In mammals, NBR1 is a ubiquitously expressed conserved protein that is associated with signaling pathways systems (consisting of ATG3, ATG4 ATG5, ATG7, ATG8, ATG10, ATG12, and ATG16). The Ubl conjugation systems are needed for the conjugation of ATG8 and phosphatidylethanolamine (PE) which allows the conjugate ATG8-PE to be anchored at the convex and concave site of the phagophore. (4) Extension of the phagophore membrane results in the engulfment of cytosolic compounds and completion of the doublemembraned autophagosome. (5) The outer membrane of mature autophagosomes fuses with the vacuolar membrane and releases the single-membraned autophagic body into the lumen of the vacuole. (6) Hydolases degrade the autophagic body and its content, and permeases recycle molecular building blocks back into the cytoplasm. Proteins analyzed in S. macrospora are indicated in red letters

and bone metabolism (Yin et al. 2019). It was also described as a binding partner of Atg8 family proteins where it acts as a receptor that mediates the docking of ubiquitinated substrates to the autophagosomal membrane protein LC3/ ATG8 (Kirkin et al. 2009; Lamark et al. 2009). In addition, in mammals, NBR1 is involved in pexophagy and aggrephagy, as well as putatively in mitophagy (Deosaran et al. 2013; Rogov et al. 2014). The mammalian NBR1 has an N-terminal PB1 (Phox and Bem1) domain followed by a ZZ-type zinc finger domain, coiled-coil domains, an Atg8interacting motif LIR (LC3 interacting region), and a Cterminal UBA (ubiquitin-associated) domain. Furthermore, a functionally uncharacterized NBR1 domain with four 
conserved tryptophan residues is a hallmark of all NBR1-like proteins (Kraft et al. 2010; Svenning et al. 2011). In plants, NBR1 plays important roles in stress response and aggrephagy (Svenning et al. 2011; Zhou et al. 2013). With the exception of Saccharomycetes, putative homologs of NBR1 have been identified throughout the eukaryotic kingdom (Svenning et al. 2011). Filamentous ascomycetes and basidiomycetes have retained a homolog of NBR1 in which the C-terminal UBA domain is absent (Kraft et al. 2010). Thus, the $S$. macrospora protein SmNBR1 lacks a UBA domain but displays all the characteristic domains of NBR1, and contains a repetition of the ZZ domain. In vivo co-localization, bimolecular fluorescence complementation (BiFC) experiments, and co-immunoprecipitation (CoIP) verified interaction of SmATG8 and SmNBR1. SmNBR1 accumulates in cytosolic "aggregates" and in vacuoles of young and old hyphae and co-localizes with SmATG8. A yeast two-hybrid analysis revealed that the LIR motif of SmNBR1 is required for the interaction with SmATG8. In a $\triangle$ Smatg8 mutant, SmNBR1 localizes to cytoplasmic aggregates or is homogenously distributed in the cytoplasm, but it was not detected in vacuoles. These findings indicate that in the absence of SmATG8 and functional autophagy, SmNBR1 cannot be transported into vacuoles.

Deletion of Smnbrl leads to impaired vegetative growth under starvation conditions. Moreover, fruiting body development was significantly delayed in the $\Delta$ Smnbrl mutant. Ascogonia and protoperithecia formed only after a prolonged time and in reduced numbers. Although transition to perithecia was observed in the $\Delta$ Smnbr1 mutant, fewer perithecia were formed in comparison with the wild type. Fruiting bodies formed in $\Delta$ Smnbrl contained drastically reduced numbers of mature, black ascospores. Thus, Smnbrl is required for proper vegetative growth, fruiting body, and ascospore differentiation. Similar to observations made in mammals (Deosaran et al. 2013), we could show that in contrast to the wild type, labeled peroxisomes were not delivered to vacuoles in the $\triangle$ Smnbrl mutant. This suggests that SmNBR1 is a pexophagy receptor (Werner et al. 2019). The human NBR1 homolog partially rescues the phenotypic defects of the $S$. macropora $\Delta$ Smnbrl deletion mutant, indicating a functional conservation of NBR1 homologs across eukaryotic kingdoms (Werner et al. 2019).

Only a few reports describe the role of selective autophagy in fungi other than in S. cerevisiae. Our results support the hypothesis that selective autophagy plays an important role in differentiation of filamentous fungi and that the cargo receptor NBR1 is a central component of selective autophagy. Analysis of selective autophagy in S. macrospora will help to understand how selective recycling of proteins, protein complexes, and organelles via autophagy and complex differentiation processes are mechanistically linked and regulated.

\section{Transcription factors and the role of chromatin in fruiting body development}

One of the first identified developmental genes in $S$. macrospora was the transcription factor gene prol (Masloff et al. 1999). Although PRO1 was hypothesized early on to be involved in regulating the expression of downstream genes involved in fruiting body development (Masloff et al. 1999; Masloff et al. 2002), direct target genes of PRO1 were identified only years later by ChIP-seq (Steffens et al. 2016). These analyses confirmed that indeed PRO1 is involved in regulating the expression of a number of genes with a role in fruiting body morphogenesis.

Transcriptomics analysis of young fruiting bodies of the wild type and the pro1 mutant identified more than 400 genes that are differentially regulated during development and are dependent on prol for correct expression, although this control might be indirect (Teichert et al. 2012). One of these genes encodes the developmental transcription factor PRO44, which was subsequently shown to be strongly expressed in cells of the outer layers of the developing fruiting body (Schumacher et al. 2018). Transcriptomics analyses of young fruiting bodies of a $\Delta$ pro44 mutant identified another transcription factor gene, asm2, which is downregulated in $\Delta$ pro44 fruiting body precursors. Deletion of asm 2 leads to problems late in fruiting body development, namely with ascospore maturation and discharge (Schumacher et al. 2018). Thus, the three transcription factor genes pro1, pro 44 , and asm 2 are part of a genetic network regulating the progression of fruiting body development.

Another finding of genome-wide expression analyses in young fruiting bodies was that gene expression patterns in young fruiting bodies differ greatly from those of vegetative mycelia (Teichert et al. 2012; Schumacher et al. 2018). This finding is not restricted to $S$. macrospora, but can be observed also in comparative transcriptomics studies with other, distantly related ascomycetes, allowing for the identification of evolutionary conserved expression patterns during development (Lütkenhaus et al. 2019). Since ascomycete fruiting bodies contain many cell types that do not occur in vegetative mycelia (Bistis et al. 2003; Lord and Read 2011), it is thought that the massive changes in the transcriptome might reflect the requirement for major changes in metabolic activity and their regulation during the formation of the fruiting body. Transcription factors will be involved in mediating these changes; however, results in recent years indicate that other factors that influence the structure and function of chromatin also play a role in fruiting body development.

In $S$. macrospora, the first chromatin modifier to be identified as a developmental gene was asfl, which encodes a histone H3/H4 chaperone (Gesing et al. 2012). Histone chaperones comprise a diverse group of proteins that handle nonnucleosomal histones in vivo, and in vitro can mediate the 
assembly of nucleosomes from isolated histones and DNA (Hammond et al. 2017). A $\Delta$ asfl mutant has a block during early stages of fruiting body development, and transcriptomics analyses of the mutant showed that asfl acts as a suppressor of weakly expressed genes during development (Gesing et al. 2012; Schumacher et al. 2018). How ASF1 might mediate gene expression changes is not clear yet. Genome-wide analyses of nucleosome positioning as well as cytosine methylation in the $\Delta$ asfl mutant compared with the wild type failed to identify changes that would explain the expression changes specifically in weakly expressed genes (Schumacher et al. 2018); therefore, additional analyses, for example of histone modifications, will be needed to address this question.

Another chromatin modifier recently identified to be required for fruiting body formation in $S$. macrospora is spt3 (Lütkenhaus et al. 2019). spt3 encodes a homolog to the SPT3 subunit of the SAGA complex, which is a conserved eukaryotic transcriptional co-activator complex with multiple functions in histone modification and interactions with other transcriptional activators (Spedale et al. 2012; Helmlinger and Tora 2017). A $\Delta$ spt3 mutant shows reduced vegetative growth and an early block during fruiting body development, similar to a previously characterized spt3 mutant of Fusarium graminearum (Gao et al. 2014; Lütkenhaus et al. 2019).

Several other putative chromatin modifier genes were analyzed for their role in sexual development in S. macrospora, but none of them showed such a drastic phenotype as observed for asf 1 and spt3. Single mutants of the genes for the histone $\mathrm{H} 3 / \mathrm{H} 4$ chaperones $\mathrm{cac} 2$ and $\mathrm{rtt106}$, as well as the putative chromatin modifiers $\mathrm{crcl}$ and $\mathrm{scml}$, were fertile, and even all combinations of double mutants turned out to be fertile (Gesing et al. 2012; Schumacher et al. 2018; Lütkenhaus et al. 2019). However, all possible combinations of triple mutants showed different degrees of reduction in fertility, and the quadruple mutant $\Delta \mathrm{cac} 2 / \Delta \mathrm{crc} 1 / \Delta \mathrm{rtt} 106 /$ $\Delta \mathrm{scm} 1$ turned out to be completely sterile with a block during early stages of fruiting body development (Lütkenhaus et al. 2019). Addressing the question if the corresponding proteins have redundant roles in the same pathway or are essential components of different regulatory pathways with redundant functions will be part of future studies. Another important question for future analyses is how the activity of chromatin modifiers is integrated with the activity of specific transcription factors like PRO1, PRO44, or ASM2.

\section{RNA editing: a new paradigm in fruiting body development of filamentous ascomycetes}

RNA editing comprises nucleotide substitutions or short insertions/deletions within transcripts that could alternatively be directly encoded at the DNA level (Knoop 2011). Editing occurs in diverse RNA species across kingdoms. The existence of RNA editing of nuclear-encoded protein-coding transcripts was only recently described in fungi (Liu et al. 2016; Liu et al. 2017; Teichert et al. 2017a). By a yet unknown catalytic activity, adenosin (A) is desaminated to inosin (I). Since I pairs with cytidine, the structure of edited RNAs can differ from the native, genome-encoded structure. Furthermore, the ribosome interprets I as guanosin $(\mathrm{G})$, which may lead to amino acid exchanges in the encoded proteins.

First evidence that S. macrospora transcripts undergo A-toI RNA editing came from RNA-seq data generated from wild type and mutant protoperithecia (Teichert et al. 2012; Dirschnabel et al. 2014; Teichert et al. 2017a). In wild type protoperithecia, but not in wild type vegetative mycelial samples or in mutant protoperithecia, the level of A-to-G exchanges indicative of A-to-I editing increased significantly (Teichert et al. 2017a). This is in accordance with data from other filamentous ascomycetes, where editing levels increase with the progression of fruiting body formation (Liu et al. 2016; Liu et al. 2017; Teichert et al. 2017a).

Interestingly, editing sites in fungi occur mostly in coding regions, which is in contrast to metazoan species, where editing sites reside mostly in non-coding regions (Teichert 2018; Bian et al. 2019). Thus, fungal RNA editing mostly leads to coding changes, which in turn may lead to single amino acid variations (SAAVs). Indeed, SAAVs were identified in protein extracts from sexually developed cultures by proteogenomics analysis (Blank-Landeshammer et al. 2019). Quantitative mass spectrometry with synthetic peptides showed that the level of modified peptides increased with progression of fruiting body formation. This is in accordance with transcriptomics data and strengthens the hypothesis that editing may be required for late stages of fruiting body formation and the generation of ascospores.

Another feature of fungal editing is the targeting of stop codons. Either premature stop codons within wrongly annotated open reading frames are "corrected", i.e., during fruiting body formation, a functional protein is formed, or the annotated translational stop is targeted, leading to C-terminal elongation of proteins (Liu et al. 2016; Liu et al. 2017; Teichert et al. 2017a). Like with SAAVs, peptides from C-terminally elongated proteins can be detected in protein extracts from cultures generating fruiting bodies (Blank-Landeshammer et al. 2019). In silico analysis predicts new linear motifs, localization signals, or even protein domains in these elongations. For example, the blue light sensor and transcription factor White Collar 1 gains a histone deacetylase domain by RNA editing of its transcripts at late stages of fruiting body formation (Blank-Landeshammer et al. 2019). Why proteins need these new functions during development, if A-to-I RNA editing is a prerequisite for ascospore formation, how editing is catalyzed in fungi, and how it evolved are open questions that have to be answered by future research. 


\section{Conclusions}

The year 2020 marks the 25th anniversary of $S$. macrospora entering the world of molecular biology as a model organism for fungal development. More than 50 developmental genes have been characterized during that time, and a better picture of the molecular processes involved in fruiting body development is starting to emerge. Future challenges include the open question of how the different regulatory and metabolic processes needed to build a fruiting body are orchestrated in time and space. However, with its complement of classical genetics, molecular, and "omics" tools and resources available, S. macrospora is an excellent model organism to tackle these exciting questions.

Author contributions MN, IT, and SP wrote the manuscript. All authors read and approved the manuscript.

Funding information Open Access funding provided by Projekt DEAL. The authors are funded by the German Research Foundation (DFG, grant NO407/7-1 to MN, grant PO523/8-1 to SP, grant TE977/2-1 to IT).

\section{Compliance with ethical standards}

Conflict of interest The authors declare that they have no conflict of interest.

Ethical approval This article does not contain any studies with human participants or animals performed by any of the authors.

Open Access This article is licensed under a Creative Commons Attribution 4.0 International License, which permits use, sharing, adaptation, distribution and reproduction in any medium or format, as long as you give appropriate credit to the original author(s) and the source, provide a link to the Creative Commons licence, and indicate if changes were made. The images or other third party material in this article are included in the article's Creative Commons licence, unless indicated otherwise in a credit line to the material. If material is not included in the article's Creative Commons licence and your intended use is not permitted by statutory regulation or exceeds the permitted use, you will need to obtain permission directly from the copyright holder. To view a copy of this licence, visit http://creativecommons.org/licenses/by/4.0/.

\section{References}

Aguirre J, Lambeth JD (2010) Nox enzymes from fungus to fly to fish and what they tell us about Nox function in mammals. Free Radic Biol Med 49:1342-1353

Bartoszewska M, Kiel JA (2011) The role of macroautophagy in development of filamentous fungi. Antioxid Redox Signal 14:2271-2287

Beier A, Teichert I, Krisp C, Wolters DA, Kück U (2016) Catalytic subunit 1 of protein phosphatase $2 \mathrm{~A}$ is a subunit of the STRIPAK complex and governs fungal sexual development. mBio 7: e00870-e00816

Bernhards Y, Pöggeler S (2011) The phocein homologue SmMOB3 is essential for vegetative cell fusion and sexual development in the filamentous ascomycete Sordaria macrospora. Curr Genet 57:133149

Bian Z, Ni Y, Xu JR, Liu H (2019) A-to-I mRNA editing in fungi: occurrence, function, and evolution. Cell Mol Life Sci 76:329-340

Bistis GN, Perkins DD, Read ND (2003) Different cell types in Neurospora crassa. Fungal Genet Newsl 50:17-19

Blank-Landeshammer B, Teichert I, Märker R, Nowrousian M, Kück U, Sickmann A (2019) Combination of proteogenomics with peptide de novo sequencing identifies new genes and hidden posttranscriptional modifications. mBio 10:e02367-e02319

Bloemendal S, Lord KM, Rech C, Hoff B, Engh I, Read ND, Kück U (2010) A mutant defective in sexual development produces aseptate ascogonia. Eukaryot Cell 9:1856-1866

Bloemendal S, Bernhards Y, Bartho K, Dettmann A, Voigt O, Teichert I, Seiler S, Wolters DA, Pöggeler S, Kück U (2012) A homolog of the human STRIPAK complex controls sexual development in fungi. Mol Microbiol 84:310-323

Deosaran E, Larsen KB, Hua R, Sargent G, Wang Y, Kim S, Lamark T, Jauregui M, Law K, Lippincott-Schwartz J, Brech A, Johansen T, Kim PK (2013) NBR1 acts as an autophagy receptor for peroxisomes. J Cell Sci 126:939-952

Dirschnabel DE, Nowrousian M, Cano-Domínguez N, Aguirre J, Teichert I, Kück U (2014) New insights into the roles of NADPH oxidases in sexual development and ascospore germination in Sordaria macrospora. Genetics 196:729-744

Elleuche S, Pöggeler S (2009) $\beta$-carbonic anhydrases play a role in fruiting body development and ascospore germination in the filamentous fungus Sordaria macrospora. PLOS One 4:e5177

Engh I, Nowrousian M, Kück U (2007a) Regulation of melanin biosynthesis via the dihydroxynaphtalene pathway is dependent on sexual development in the ascomycete Sordaria macrospora. FEMS Microbiol Lett 275:62-70

Engh I, Würtz C, Witzel-Schlömp K, Zhang HY, Hoff B, Nowrousian M, Rottensteiner H, Kück U (2007b) The WW domain protein PRO40 is required for fungal fertility and associates with Woronin bodies. Eukaryot Cell 6:831-843

Engh I, Nowrousian M, Kück U (2010) Sordaria macrospora, a model organism to study fungal cellular development. Eur J Cell Biol 89: 864-872

Esser K, Straub J (1956) Fertility in the heterokaryon from two sterile mutants of Sordaria macrospora Auersw. Z Indukt Abstamm Vererbungs1 87:625-626

Esser K, Straub J (1958) Genetische Untersuchungen an Sordaria macrospora Auersw., Kompensation und Induktion bei genbedingten Entwicklungsdefekten. Z Vererbungs1 98:729-746

Farré JC, Subramani S (2016) Mechanistic insights into selective autophagy pathways: lessons from yeast. Nat Rev Mol Cell Biol 17:537552

Frey S, Lahmann Y, Hartmann T, Seiler S, Pöggeler S (2015a) Deletion of Smgpil encoding a GPI-anchored protein suppresses sterility of the STRIPAK mutant $\Delta$ Smmob3 in the filamentous ascomycete Sordaria macrospora. Mol Microbiol 97:676-697

Frey S, Reschka EJ, Pöggeler S (2015b) Germinal center kinases SmKIN3 and SmKIN24 are associated with the Sordaria macrospora striatin-interacting phosphatase and kinase (STRIPAK) complex. PLoS One 10:e139163

Gao T, Zheng Z, Hou Y, Zhou M (2014) Transcription factors spt3 and spt8 are associated with conidiation, mycelium growth, and pathogenicity in Fusarium graminearum. FEMS Microbiol Lett 351:4250

Gesing S, Schindler D, Fränzel B, Wolters D, Nowrousian M (2012) The histone chaperone ASF1 is essential for sexual development in the filamentous fungus Sordaria macrospora. Mol Microbiol 84:748765

Goudreault M, D'Ambrosio LM, Kean MJ, Mullin MJ, Larsen BG, Sanchez A, Chaudhry S, Chen GI, Sicheri F, Nesvizhskii AI, 
Aebersold R, Raught B, Gingras AC (2009) A PP2A phosphatase high density interaction network identifies a novel striatininteracting phosphatase and kinase complex linked to the cerebral cavernous malformation $3(\mathrm{CCM} 3)$ protein. Mol Cell Proteomics 8: $157-171$

Hammond CM, Strømme CB, Huang H, Patel DJ, Groth A (2017) Histone chaperone networks shaping chromatin function. Nat Rev Mol Cell Biol 18:141-158

Heller J, Tudzynski P (2011) Reactive oxygen species in phytopathogenic fungi: signaling, development, and disease. Annu Rev Phytopathol 49:369-390

Helmlinger D, Tora L (2017) Sharing the SAGA. Trends Biochem Sci 42: $850-861$

Kamerewerd J, Jansson M, Nowrousian M, Pöggeler S, Kück U (2008) Three alpha subunits of heterotrimeric $\mathrm{G}$ proteins and an adenylyl cyclase have distinct roles in fruiting body development in the homothallic fungus Sordaria macrospora. Genetics 180:191-206

Kirisako T, Ichimura Y, Okada H, Kabeya Y, Mizushima N, Yoshimori T, Ohsumi M, Takao T, Noda T, Ohsumi Y (2000) The reversible modification regulates the membrane-binding state of Apg8/Aut7 essential for autophagy and the cytoplasm to vacuole targeting pathway. J Cell Biol 151:263-237

Kirkin V, Lamark T, Sou YS, Bjørkøy G, Nunn JL, Bruun JA, Shvets E, McEwan DG, Clausen TH, Wild P, Bilusic I, Theurillat JP, Øvervatn A, Ishii T, Elazar Z, Komatsu M, Dikic I, Johansen T (2009) A role for NBR1 in autophagosomal degradation of ubiquitinated substrates. Mol Cell 33:505-516

Klix V, Nowrousian M, Ringelberg C, Loros JJ, Dunlap JC, Pöggeler S (2010) Functional characterization of MAT1-1-specific mating-type genes in the homothallic ascomycete Sordaria macrospora provides new insights into essential and non-essential sexual regulators. Eukaryot Cell 9:894-905

Knoop V (2011) When you can't trust the DNA: RNA editing changes transcript sequences. Cell Mol Life Sci 68:567-586

Kraft C, Peter M, Hofmann K (2010) Selective autophagy: ubiquitin-mediated recognition and beyond. Nat Cell Biol $12: 836-841$

Kück U (2005) A Sordaria macrospora mutant lacking the leul gene shows a developmental arrest during fruiting body formation. Mol Gen Genomics 274:307-315

Kück U, Pöggeler S, Nowrousian M, Nolting N, Engh I (2009) Sordaria macrospora, a model system for fungal development. In: Anke T, Weber D (eds) The mycota XV, physiology and genetics. Springer, Heidelberg, pp 17-39

Kück U, Beier AM, Teichert I (2016) The composition and function of the striatin-interacting phosphatases and kinases (STRIPAK) complex in fungi. Fungal Genet Biol 90:31-38

Lacaze I, Lalucque H, Siegmund U, Silar P, Brun S (2015) Identification of NoxD/Pro41 as the homologue of the p22phox NADPH oxidase subunit in fungi. Mol Microbiol 95:1006-1024

Lamark T, Kirkin V, Dikic I, Johansen T (2009) NBR1 and p62 as cargo receptors for selective autophagy of ubiquitinated targets. Cell Cycle 8:1986-1990

Lambeth JD (2004) NOX enzymes and the biology of reactive oxygen. Nat Rev Immunol 4:181-189

Lehneck R, Elleuche S, Pöggeler S (2014) The filamentous ascomycete Sordaria macrospora can survive in ambient air without carbonic anhydrases. Mol Microbiol 92:931-944

Lewis ZA, Correa A, Schwerdtfeger C, Link KL, Xie X, Gomer RH, Thomas T, Ebbole DJ, Bell-Pedersen D (2002) Overexpression of white collar-1 (WC-1) activates circadian clock-associated genes, but is not sufficient to induce most light-regulated gene expression in Neurospora crassa. Mol Microbiol 45:917-931

Li R, Fan W, Tian G, Zhu H, He L, Cai J, Huang Q, Cai Q, Li B, Bai Y, Zhang Z, Zhang Y, Wang W, Li J, Wei F, Li H, Jian M, Li J, Zhang Z, Nielsen R, Li D, Gu W, Yang Z, Xuan Z, Ryder OA, Leung FC-C,
Zhou Y, Cao J, Sun X, Fu Y, Fang X, Guo X, Wang B, Hou R, Shen F, Mu B, Ni P, Lin R, Qian W, Wang G, Yu C, Nie W, Wang J, Wu Z, Liang H, Min J, Wu Q, Cheng S, Ruan J, Wang M, Shi Z, Wen M, Liu B, Ren X, Zheng H, Dong D, Cook K, Shan G, Zhang H, Kosiol C, Xie X, Lu Z, Zheng H, Li Y, Steiner CC, Lam TT-Y, Lin S, Zhang Q, Li G, Tian J, Gong T, Liu H, Zhang D, Fang L, Ye C, Zhang J, Hu W, Xu A, Ren Y, Zhang G, Bruford MW, Li Q, Ma L, Guo Y, An N, Hu Y, Zheng Y, Shi Y, Li Z, Liu Q, Chen Y, Zhao J, Qu N, Zhao S, Tian F, Wang X, Wang H, Xu L, Liu X, Vinar T, Wang Y, Lam T-W, Yiu S-M, Liu S, Zhang H, Li D, Huang Y, Wang X, Yang G, Jiang Z, Wang J, Qin N, Li L, Li J, Bolund L, Kristiansen K, Wong GK-S, Olson M, Zhang X, Li S, Yang H, Wang J, Wang J (2010) The sequence and de novo assembly of the giant panda genome. Nature 463:311-317

Liu H, Wang Q, He Y, Chen L, Hao C, Jiang C, Li Y, Dai YC, Kang Z, Xu JR (2016) Genome-wide A-to-I RNA editing in fungi independent of ADAR enzymes. Genome Res 26:499-509

Liu H, Li Y, Chen DC, Qi Z, Wang Q, Wang J, Jiang C, Xu JR (2017) Ato-I RNA editing is developmentally regulated and generally adaptive for sexual reproduction in Neurospora crassa. Proc Natl Acad Sci U S A 114:E7756-E7765

Lord KM, Read ND (2011) Perithecium morphogenesis in Sordaria macrospora. Fungal Genet Biol 49:388-399

Lütkenhaus R, Traeger S, Breuer J, Carreté L, Kuo A, Lipzen A, Pangilinan J, Dilworth D, Sandor L, Pöggeler S, Gabaldón T, Barry K, Grigoriev IV, Nowrousian M (2019) Comparative genomics and transcriptomics to analyze fruiting body development in filamentous ascomycetes. Genetics 213:1545-1563. https://doi.org/ 10.1534/genetics.119.302749

Masloff S, Pöggeler S, Kück U (1999) The pro1+ gene from Sordaria macrospora encodes a $\mathrm{C}_{6}$ zinc finger transcription factor required for fruiting body development. Genetics 152:191-199

Masloff S, Jacobsen S, Pöggeler S, Kück U (2002) Functional analysis of the $\mathrm{C}_{6}$ zinc finger gene prol involved in fungal sexual development. Fungal Genet Biol 36:107-116

Mayrhofer S, Pöggeler S (2005) Functional characterization of an \{alpha\}-factor-like Sordaria macrospora peptide pheromone and analysis of its interaction with its cognate receptor in Saccharomyces cerevisiae. Eukaryot Cell 4:661-672

Mayrhofer S, Weber JM, Pöggeler S (2006) Pheromones and pheromone receptors are required for proper sexual development in the homothallic ascomycete Sordaria macrospora. Genetics 172:1521-1533

Nagy LG, Kovács GM, Krizsán K (2018) Complex multicellularity in fungi: evolutionary convergence, single origin, or both. Biol Rev 93: $1778-1794$

Nolting N, Pöggeler S (2006a) A STE12 homologue of the homothallic ascomycete Sordaria macrospora interacts with the MADS box protein MCM1 and is required for ascosporogenesis. Mol Microbiol 62:853-868

Nolting N, Pöggeler S (2006b) A MADS box protein interacts with a mating-type protein and is required for fruiting body development in the homothallic ascomycete Sordaria macrospora. Eukaryot Cell 5:1043-1056

Nolting N, Bernhards Y, Pöggeler S (2009) SmATG7 is required for viability in the homothallic ascomycete Sordaria macrospora. Fungal Genet Biol 46:531-542

Nordzieke S, Zobel T, Fränzel B, Wolters DA, Kück U, Teichert I (2015) A fungal SLMAP homolog plays a fundamental role in development and localizes to the nuclear envelope, ER, and mitochondria. Eukaryot Cell 14:345-358

Nowrousian M (2009) A novel polyketide biosynthesis gene cluster is involved in fruiting body morphogenesis in the filamentous fungi Sordaria macrospora and Neurospora crassa. Curr Genet 55:185198 
Nowrousian M, Masloff S, Pöggeler S, Kück U (1999) Cell differentiation during sexual development of the fungus Sordaria macrospora requires ATP citrate lyase activity. Mol Cell Biol 19:450-460

Nowrousian M, Duffield GE, Loros JJ, Dunlap JC (2003) The frequency gene is required for temperature-dependent regulation of many clock-controlled genes in Neurospora crassa. Genetics 164:923933

Nowrousian M, Würtz C, Pöggeler S, Kück U (2004) Comparative sequence analysis of Sordaria macrospora and Neurospora crassa as a means to improve genome annotation. Fungal Genet Biol 41:285292

Nowrousian M, Ringelberg C, Dunlap JC, Loros JJ, Kück U (2005) Cross-species microarray hybridization to identify developmentally regulated genes in the filamentous fungus Sordaria macrospora. Mol Gen Genomics 273:137-149

Nowrousian M, Frank S, Koers S, Strauch P, Weitner T, Ringelberg C, Dunlap JC, Loros JJ, Kück U (2007) The novel ER membrane protein PRO41 is essential for sexual development in the filamentous fungus Sordaria macrospora. Mol Microbiol 64:923-937

Nowrousian M, Stajich JE, Chu M, Engh I, Espagne E, Halliday K, Kamerewerd J, Kempken F, Knab B, Kuo HC, Osiewacz HD, Pöggeler S, Read ND, Seiler S, Smith KM, Zickler D, Kück U, Freitag M (2010) De novo assembly of a $40 \mathrm{Mb}$ eukaryotic genome from short sequence reads: Sordaria macrospora, a model organism for fungal morphogenesis. PLoS Genet 6:e1000891

Nowrousian M, Teichert I, Masloff S, Kück U (2012) Whole-genome sequencing of Sordaria macrospora mutants identifies developmental genes. G3 (Bethesda) 2:261-270

Ohsumi Y (2001) Molecular dissection of autophagy: two ubiquitin-like systems. Nat Rev Mol Cell Biol 2:211-216

Ohsumi Y (2014) Historical landmarks of autophagy research. Cell Res 24:9-23

Pöggeler S, Kück U (2004) A WD40 repeat protein regulates fungal cell differentiation and can be replaced functionally by the mammalian homologue striatin. Eukaryot Cell 3:232-240

Pöggeler S, Kück U (2006) Highly efficient generation of signal transduction knockout mutants using a fungal strain deficient in the mammalian $k u 70$ ortholog. Gene 378:1-10

Pöggeler S, Nowrousian M, Jacobsen S, Kück U (1997) An efficient procedure to isolate fungal genes from an indexed cosmid library. J Microbiol Meth 29:49-61

Pöggeler S, Masloff S, Hoff B, Mayrhofer S, Kück U (2003) Versatile EGFP reporter plasmids for cellular localization of recombinant gene products in filamentous fungi. Curr Genet 43:54-61

Pöggeler S, Nowrousian M, Ringelberg C, Loros JJ, Dunlap JC, Kück U (2006) Microarray and real time PCR analyses reveal mating typedependent gene expression in a homothallic fungus. Mol Gen Genomics 275:492-503

Pöggeler S, Nowrousian M, Teichert I, Beier A, Kück U (2018) Fruiting body development in ascomycetes. In: Anke T, Schüffler A (eds) The mycota XV, physiology and genetics, 2nd edn. Springer, BerlinHeidelberg

Radchenko D, Teichert I, Pöggeler S, Kück U (2018) A Hippo pathwayrelated GCK controls both sexual and vegetative developmental processes in the fungus Sordaria macrospora. Genetics 210:137153

Rech C, Engh I, Kück U (2007) Detection of hyphal fusion in filamentous fungi using differently fluorescene-labeled histones. Curr Genet 52: 259-266

Reschka EJ, Nordzieke S, Valerius O, Braus GH, Pöggeler S (2018) A novel STRIPAK complex component mediates hyphal fusion and fruiting-body development in filamentous fungi. Mol Microbiol 110:513-532

Rogov V, Dötsch V, Johansen T, Kirkin V (2014) Interactions between autophagy receptors and ubiquitin-like proteins form the molecular basis for selective autophagy. Mol Cell 53:167-178
Schindler D, Nowrousian M (2014) The polyketide synthase gene $p k s 4$ is essential for sexual development and regulates fruiting body morphology in Sordaria macrospora. Fungal Genet Biol 68:48-59

Schumacher DI, Lütkenhaus R, Altegoer F, Teichert I, Kück U, Nowrousian M (2018) The transcription factor PRO44 and the histone chaperone ASF1 regulate distinct aspects of multicellular development in the filamentous fungus Sordaria macrospora. BMC Genet 19:112

Scott B, Eaton CJ (2008) Role of reactive oxygen species in fungal cellular differentiations. Curr Opin Microbiol 11:488-493

Siegmund U, Marschall R, Tudzynski P (2015) BcNoxD, a putative ER protein, is a new component of the NADPH oxidase complex in Botrytis cinerea. Mol Microbiol 95:988-1005

Spedale G, Timmers HT, Pijnappel WW (2012) ATAC-king the complexity of SAGA during evolution. Genes Dev 26:527-541

Steffens EK, Becker K, Krevet S, Teichert I, Kück U (2016) Transcription factor PRO1 targets genes encoding conserved components of fungal developmental signaling pathways. Mol Microbiol 102:792-809

Svenning S, Lamark T, Krause K, Johansen T (2011) Plant NBR1 is a selective autophagy substrate and a functional hybrid of the mammalian autophagic adapters NBR1 and p62/SQSTM1. Autophagy 7: 993-1010

Teichert I (2018) Adenosine to inosine mRNA editing in fungi and how it may relate to fungal pathogenesis. PLoS Pathog 14:e1007231

Teichert I, Wolff G, Kück U, Nowrousian M (2012) Combining laser microdissection and RNA-seq to chart the transcriptional landscape of fungal development. BMC Genomics 13:511

Teichert I, Nowrousian M, Pöggeler S, Kück U (2014a) The filamentous fungus Sordaria macrospora as a genetic model to study fruiting body development. Adv Genet 87:199-244

Teichert I, Steffens EK, Schnaß N, Fränzel B, Krisp C, Wolters DA, Kück $\mathrm{U}$ (2014b) PRO40 is a scaffold protein of the cell wall integrity pathway, linking the MAP kinase module to the upstream activator protein kinase C. PLoS Genet 10:e1004582

Teichert I, Dahlmann T, Kück U, Nowrousian M (2017a) RNA editing during sexual development occurs in distantly related filamentous ascomycetes. Genome Biol Evol 9:855-868

Teichert I, Lutomski M, Märker R, Nowrousian M, Kück U (2017b) New insights from an old mutant: SPADIX4 governs fruiting body development but not hyphal fusion in Sordaria macrospora. Mol Gen Genomics 292:93-104

Traeger S, Nowrousian M (2015) Functional analysis of developmentally regulated genes chs 7 and sec 22 in the ascomycete Sordaria macrospora. G3 (Bethesda) 5:1233-1245

Traeger S, Altegoer F, Freitag M, Gabaldon T, Kempken F, Kumar A, Marcet-Houben M, Pöggeler S, Stajich JE, Nowrousian M (2013) The genome and development-dependent transcriptomes of Pyronema confluens: a window into fungal evolution. PLoS Genet 9:e1003820

Voigt O, Pöggeler S (2013a) Autophagy genes Smatg8 and Smatg4 are required for fruiting-body development, vegetative growth and ascospore germination in the filamentous ascomycete Sordaria macrospora. Autophagy 9:33-49

Voigt O, Pöggeler S (2013b) Self-eating to grow and kill: autophagy in filamentous ascomycetes. Appl Microbiol Biotechnol 97:92779290

Voigt O, Herzog B, Jakobshagen A, Pöggeler S (2013) bZIP transcription factor SmJLB1 regulates autophagy-related genes Smatg 8 and Smatg4 and is required for fruiting-body development and vegetative growth in Sordaria macrospora. Fungal Genet Biol 61:50-60

Voigt O, Herzog B, Jakobshagen A, Pöggeler S (2014) Autophagic kinases SmVPS34 and SmVPS15 are required for viability in the filamentous ascomycete Sordaria macrospora. Microbiol Res 169: $128-138$ 
Walz M, Kück U (1995) Transformation of Sordaria macrospora to hygromycin B resistance: characterization of transformants by electrophoretic karyotyping and tetrad analysis. Curr Genet 29:88-95

Wen X, Klionsky DJ (2016) An overview of macroautophagy in yeast. J Mol Biol 428:1681-1699

Werner A, Herzog B, Frey S, Pöggeler S (2016) Autophagy-associated protein SmATG12 is required for fruiting-body formation in the filamentous ascomycete Sordaria macrospora. PLoS One 11: e0157960

Werner A, Herzog B, Voigt O, Valerius O, Braus GH, Pöggeler S (2019) NBR1 is involved in selective pexophagy in filamentous ascomycetes and can be functionally replaced by a tagged version of its human homolog. Autophagy 15:78-97

Yin X, Zhou C, Li J, Liu R, Shi B, Yuan Q, Zou S (2019) Autophagy in bone homeostasis and the onset of osteoporosis. Bone Res 7:28
Zhou JJ, Wang J, Cheng Y, Chi YJ, Fan B, Yu JQ, Chen Z (2013) NBR1mediated selective autophagy targets insoluble ubiquitinated protein aggregates in plant stress responses. PLoS Genet 9:e1003196

Zhu XM, Li L, Wu M, Liang S, Shi HB, Liu XH, Lin FC (2019) Current opinions on autophagy in pathogenicity of fungi. Virulence 10:481489

Zickler D, Espagne E (2016) Sordaria, a model system to uncover links between meiotic pairing and recombination. Semin Cell Dev Biol 54:149-157

Publisher's note Springer Nature remains neutral with regard to jurisdictional claims in published maps and institutional affiliations. 